\title{
Minimum Wage Impacts on Older Workers: Longitudinal Estimates from Canada
}

\author{
Tony Fang and Morley Gunderson
}

\begin{abstract}
We use the longitudinal nature of the master file of the Survey of Labour and Income Dynamics in Canada for the period 1993-99 to estimate the employment impacts for older workers of the large number (24) of minimum wage increases that have occurred across the different provincial jurisdictions over that period. Perhaps somewhat surprisingly, the minimum wage increases have positive impacts on the employment of older workers compared with the negative impacts that are commonly estimated for youths in Canada. The results are robust across various comparison groups and measures of the minimum wage increases. Reasons for this unusual finding are discussed.
\end{abstract}

\section{Introduction}

The literature on estimating minimum wage impacts is extensive. ${ }^{1}$ The focus of these studies almost invariably has been on youths. This is understandable given that youths tend to be at the lower end of the wage distribution, and hence are most likely to be affected by minimum wages. To our knowledge, there are no studies that focus on the impact on older workers. This lack of evidence for older workers may be understandable in the past, when there were few older workers in the workforce, and their typical pattern was to work often at blue-collar jobs until they retire and then to completely retire. Few such workers would likely have wages that were at or near the minimum.

The new world of work, however, is vastly different. Older workers constitute a larger portion of the workforce, and this is expected to grow into the future. For example, in the $25 \mathrm{EU}$ member countries, the share of older workers age 55-64 is expected to increase from 10 per cent in 2003 to 18 per

Tony Fang is at York University School of Administrative Studies and Morley Gunderson is at the University of Toronto Centre for Industrial Relations and Human Resources and the Department of Economics. 
cent by 2050 (Carone 2005: 63-7). In the USA, the share of older workers age 55 and over will increase from 11.9 per cent in 1994 to 15.6 per cent in 2004, to 21.2 per cent as soon as 2014 (Tossi 2005). In Canada, the share of older workers age 55 and over in the workforce is expected to grow from around 14 per cent in 2005 to around 20 per cent as soon as 2021 (Martel et al. 2007). Calculations based on United Nations (2002) data indicate that the share of those age 50-64 in the labour force is expected to grow over the period between 1980 and 2020 from 16.4 to 26.7 per cent in the EU, from 15.7 to 22 per cent in the USA, and from 14.8 to 24.7 per cent in Canada. This growing share of older workers in the workforce reflects a number of factors. The population itself is ageing, as the large baby-boom population matures and lives longer, and the share of younger workers declines as fertility rates drop. The older population is also more likely to continue to work in the labour market, as the trend towards earlier retirement has reversed itself in recent years as a result of a number of factors: the shift from blue-collar work to white-collar work, the increase in non-standard and flexible worktime arrangements, the dissipation of mandatory retirement and a growing emphasis on combating age discrimination, more job opportunities associated with the growing labour shortages, and the complementarities between husbands working longer and their spouses who are more likely to be employed.

As part of the process of working more, older workers are phasing into retirement utilizing bridge jobs that pay lower wages than their former main job. Increasingly, they are also returning to the labour force from retirement, often in service jobs and non-standard employment, such as part-time work and limited-term contracts (Gomez and Gunderson 2005). In these circumstances, older workers are more likely to be working at jobs where pay is low, and, therefore, more likely to be subject to minimum wages.

In such circumstances, the implications of minimum wages for older workers are taking on increased practical and policy importance and will likely do so even more in the future. The purpose of this article is to begin to fill the gap that exists in the literature with respect to the impact of minimum wages on older workers. To our knowledge, this is the first study that focuses on older workers. Our empirical methodology is laid out in the next section. This is followed by a discussion of our data and the unique strengths of Canadian data for testing minimum wage impacts. Our empirical results are then discussed, as is their sensitivity to a wide range of specifications. Since our results are unusual and possibly unexpected - minimum wages are associated with increases in the employment of older workers compared with decreases in the employment of youths - our concluding section spends considerable time discussing plausible reasons for our results.

\section{Empirical methodology}

Our empirical methodology follows that of the previous analysis in Campolieti et al. (2005a) for youths, thereby also facilitating comparisons of the 
effects on older workers compared to youths. Our estimates are based on the 'at-risk' methodology ${ }^{2}$ that utilizes longitudinal data to compare employment transition probabilities of workers affected by minimum wage increases with comparison groups not affected by minimum wage increases. Essentially, the probability of being employed in the subsequent year is estimated based on individuals as the unit of observation, with the key explanatory variable being whether an individual was in the treatment group of being 'at risk' of being affected by a minimum wage increase compared with a comparison group that was not at 'risk'. The 'at-risk' treatment group is identified as workers whose wage fell between the old minimum wage and the new minimum wage in a jurisdiction and time period where the minimum wage was increased. The comparison group is composed of workers of similar wages but whose wages were not affected by a minimum wage increase. ${ }^{3}$ Our analysis models only transitions out of employment and not from non-employment to employment since we do not have wage data on the non-employed.

We use probit analysis to estimate the probability of an individual being employed in period $t$, given that they were employed in period $t-1$ as

$$
\operatorname{Pr}\left(E_{i t}^{j}=1 \mid E_{i t-1}^{j}=1\right)=f\left(\alpha M I N W A G E_{i t}^{j}+X_{i t-1} \beta+T_{t} \delta+R_{i} \varphi+u_{i t}\right)
$$

where $E_{i t}^{j}=1$ if individual $i$ from province $j$ is employed at time $t$, and 0 if they are not employed in time period $t, M I N W A G E_{i t}^{j}=1$ if individual $i$ in province $j$ at time $t-1$ is in the 'at-risk' treatment group in that their wage falls between the old minimum wage and the new minimum wage when there is an increase in the minimum wage in province $j$ at time $t$, and $M I N W A G E_{i t}^{j}=0$ if the individual is not affected by a minimum wage increase. $X_{i t-1}$ is a vector of controls for observable characteristics for individual $i$ at time $t-1, T_{t}$ is a set of time dummies, $R_{i}$ is a set of region dummies, and $u_{i t}$ is a residual. Since the employment transition function is conditional upon being employed in period $t-1$, persons not employed in period $t-1$ are excluded, but persons in higher wage employment in period $t-1$ are included and will form part of some of the comparison groups where wages will not be affected by a minimum wage increase. The MINWAGE variable captures the effects of minimum wage increases on the probability that the at-risk group will be employed in the subsequent time period compared with the comparison group who did not experience a minimum wage increase. If minimum wage increases have their theoretically expected adverse employment effect, then the coefficient $\alpha$ on the minimum wage variable should be negative.

We use a range of comparison groups to test the sensitivity of the results to the inclusion of persons in the control group whose wage is very close (termed the 'tight' comparison group) to the minimum wage in their jurisdiction that did not have a minimum wage increase, ranging up to include persons whose wage was not so close to the minimum wage in their jurisdiction (termed the 'broader' comparison groups). Persons in the 'tighter' comparison groups are 
more likely to be similar to those in the treatment group, since their wages are close to the minimum wage in their jurisdiction so that if their jurisdiction had raised its minimum wage, they likely would have been affected. Since we are dealing only with older workers, however, these sample sizes can be small (as discussed later). As illustrated subsequently, the sample sizes are increased by expanding to broader comparison groups whose wages are further away from the minimum wage in their jurisdiction. But this comes at the expense of including persons who are less likely to be affected by a minimum wage increase if it did occur in their jurisdiction, because the wage of some will be further away from their minimum wage. Higher-wage workers, for example, are likely to be different in terms of unobserved characteristics that give them more employment stability. This likely overestimates - and hence provides an upper bound to - the minimum wage impact.

Given this trade-off, we utilize a number of comparison groups. Our tightest low-wage comparison group is those in a jurisdiction that did not have a minimum wage increase but whose wage fell within the range of the minimum wage in their jurisdiction and $\$ 0.25$ (Canadian dollars or about $£ 0.12$ British pounds) above their minimum wage. Since $\$ 0.25$ is the modal minimum wage increase that occurred over our time period, they likely would have been affected by a typical minimum wage increase that occurred over that period. At the high-wage end of the spectrum, our 'broadest' comparison group consists of all persons with a wage above the minimum wage in their province but who did not have a minimum wage increase.

While workers in our broad comparison group have greater employment stability than workers affected by minimum wages and hence are likely to provide an upper-bound estimate of the minimum wage impact, our tight comparison group is likely to have less employment stability and hence likely to provide a lower-bound estimate. This is so because our tightest comparison group of $\$ 0.25$ is based on mimicking the typical or modal minimum wage increase that occurred. As indicated in Table 1, however, there were larger minimum wage increases, ranging from $\$ 0.40$ to $\$ 1.00$ over a year. As such, the tightest comparison group would not be reflective of similar persons in provinces that did not increase their minimum wage. Since their wage is lower than such persons, they are likely to have disproportionate employment instability and hence underestimate the minimum wage impact.

Since the tightest comparison group of $\$ 0.25$ is likely to underestimate the minimum wage impact, and the broadest comparison group of all wages is likely to overestimate the minimum wage impact, we prefer a comparison group whose wage lies between their existing minimum wage and $\$ 0.50, \$ 0.75$ or $\$ 1.00$ above that wage on the grounds that this will expand the number of observations in the comparison group but restrict it to those whose hypothetical minimum wage increase would fall within the range of minimum wage increases that occurred over our data period. For that reason, they are most likely to have employment instability that is similar to the treatment groups of similar low-wage workers in the jurisdictions that experienced 
TABLE 1

Minimum Wage Rates, Canada 1993-1999

\begin{tabular}{|c|c|c|c|c|c|c|}
\hline \multirow[t]{2}{*}{ Jurisdiction } & \multicolumn{6}{|c|}{ Year } \\
\hline & 1993-1994 & 1994-1995 & 1995-1996 & 1996-1997 & $1997-1998$ & $1998-1999$ \\
\hline Newfoundland & $\$ 4.75$ & $\$ 4.75$ & $\$ 4.75$ & $\begin{array}{l}\text { 1 September } \\
\$ 5.00\end{array}$ & $\begin{array}{l}\text { 1 April } \\
\$ 5.25\end{array}$ & $\$ 5.25$ \\
\hline $\begin{array}{l}\text { Prince Edward } \\
\text { Island }\end{array}$ & $\$ 4.75$ & $\$ 4.75$ & $\$ 4.75$ & $\begin{array}{l}\text { 1 September } \\
\$ 5.15\end{array}$ & $\begin{array}{c}1 \text { September } \\
\$ 5.40\end{array}$ & $\$ 5.40$ \\
\hline Nova Scotia & $\$ 5.15$ & $\$ 5.15$ & $\$ 5.15$ & $\begin{array}{l}1 \text { October } \\
\$ 5.35\end{array}$ & $\begin{array}{c}1 \text { February } \\
\$ 5.50\end{array}$ & $\$ 5.50$ \\
\hline New Brunswick & $\$ 5.00$ & $\$ 5.00$ & $\$ 5.00$ & $\begin{array}{l}1 \text { January } \\
\$ 5.25 \\
1 \text { July } \\
\$ 5.50\end{array}$ & $\$ 5.50$ & $\$ 5.50$ \\
\hline Quebec & $\begin{array}{l}1 \text { October } \\
\$ 5.85\end{array}$ & $\begin{array}{l}1 \text { October } \\
\$ 6.00\end{array}$ & $\begin{array}{l}1 \text { October } \\
\$ 6.45\end{array}$ & $\begin{array}{l}1 \text { October } \\
\$ 6.70\end{array}$ & $\begin{array}{l}1 \text { October } \\
\$ 6.80\end{array}$ & $\begin{array}{c}1 \text { October } \\
\$ 6.90\end{array}$ \\
\hline Ontario & $\$ 6.35$ & $\begin{array}{l}1 \text { January } \\
\$ 6.70\end{array}$ & $\begin{array}{l}1 \text { January } \\
\$ 6.85\end{array}$ & $\$ 6.85$ & $\$ 6.85$ & $\$ 6.85$ \\
\hline Manitoba & $\$ 5.00$ & $\$ 5.00$ & $\begin{array}{l}1 \text { July } \\
\$ 5.25\end{array}$ & $\underset{\$ 5.40}{\text { January } 1}$ & $\$ 5.40$ & $\$ 5.40$ \\
\hline Saskatchewan & $\$ 5.35$ & $\$ 5.35$ & $\$ 5.35$ & $\begin{array}{c}1 \text { December } \\
\$ 5.60\end{array}$ & $\$ 5.60$ & $\$ 5.60$ \\
\hline Alberta & $\$ 5.00$ & $\$ 5.00$ & $\$ 5.00$ & $\$ 5.00$ & $\$ 5.00$ & $\begin{array}{l}1 \text { October } \\
\$ 5.40\end{array}$ \\
\hline $\begin{array}{l}\text { British } \\
\quad \text { Columbia }\end{array}$ & $\begin{array}{l}\text { 1 April } \\
\$ 6.00\end{array}$ & $\$ 6.00$ & $\begin{array}{l}1 \text { March } \\
\$ 6.50 \\
1 \text { October } \\
\$ 7.00\end{array}$ & $\$ 7.00$ & $\$ 7.00$ & $\begin{array}{l}\text { 1 April } \\
\$ 7.15\end{array}$ \\
\hline
\end{tabular}

Source: Human Resources Development Canada minimum wage database: hourly minimum wages for adult workers.

minimum wage increases. To determine the robustness of the results, we use a range of control groups between the tightest and broadest groups, specifically control groups with the following increments above their own minimum wage: $\$ 0.50, \$ 0.75, \$ 1.00, \$ 1.50, \$ 2.00, \$ 2.50, \$ 3.00, \$ 3.50$ and $\$ 4.00$. Our single preferred comparison group would be $\$ 1.00$, since that encompasses the actual range of minimum wage increases that occurred in our data.

Following Currie and Fallick (1996), we also experiment with a lowerbound, below the minimum wage to define the comparison group (but above the $\$ 2.00$ that is the lower limit of our data). This expands the number of observations in the control group, but at the expense of including persons who are of questionable similarity to the treatment group on the grounds that if their wage was already below the legal minimum wage in their jurisdiction, it may not increase if they had a minimum wage increase. 
Our probit analysis includes a wide range of control variables, such as gender, marital status, education, union status, industry, immigrant status, visible minority status, firm size, the provincial unemployment rate for prime age males (25-54), and region and year-specific dummy variables. The region and year dummy variables are included to control for the effect of unmeasured factors that are correlated with region and time.

The at-risk methodology does not consider the magnitudes of the wage increases induced by minimum wages, only that a minimum wage increase occurred. To capture the effect of the magnitude of the wage change, we replace the minimum wage indicator of equation (1) with a variable labelled $G A P$ defined as the magnitude of the increase in the individuals' wage necessary to bring it to the new minimum wage if the individuals were affected by a minimum wage increase, and 0 if they were not affected.

The GAP measure, however, may reflect within-group heterogeneity to the extent that individuals with a large gap may have unobserved characteristics that give rise to employment instability. To account for this, we construct a wage gap measure for all individuals. For the treatment group, the gap is defined as before - the wage adjustment necessary to bring them up to the new minimum wage. For the comparison groups, the gap is the hypothetical wage adjustment necessary to bring them up to the minimum wage bound for that particular comparison group. Including this measure for both groups essentially controls for within-group heterogeneity. To capture the additional effect of the magnitude of the minimum wage increase for the treatment group, we interact the gap measure with a dummy variable indicating that the observation is from a treatment jurisdiction that experienced a minimum wage increase, labelling this the gap variant.

\section{Data}

Our empirical work is based on the Master Files of the Survey of Labour and Income Dynamics (SLID) collected by Statistics Canada. ${ }^{4}$ Since SLID is a longitudinal dataset, it enables estimating the employment transition probabilities outlined previously. We utilize the first wave of SLID, which provides longitudinal data from 1993 to 1999 . That time period encompasses the effect of a recession in the early part of the 1990s, as well as the economic expansion of the latter part of the 1990s. Given our focus on older workers, we restrict our analysis to workers age 50 and over. As in Campolieti et al. (2005a), we also limit our data to individuals with the following characteristic: wages between the minimum wage in their jurisdiction and $\$ 50$ per hour, since wages outside this range might reflect measurement errors; those who did not move between provinces during the year, since movers could not be

linked to a minimum wage change in a particular jurisdiction; individuals not in the Yukon or Northwest territories, since individuals were nor surveyed for those jurisdictions; and individuals with one job so as to avoid complications associated with tracing the employment changes of multiple job holders. 
Our employment dependent variable is coded 1 if the individual is employed in January of the current year and was also employed in January of the previous year, 0 if otherwise, since SLID collects information on the survey respondents in January.

Table 1 illustrates the substantial variation in minimum wages (24 increases) that have occurred both over time and across jurisdictions. The Canadian data is internationally recognized as ideal for estimating minimum wage impacts, since minimum wage are under provincial jurisdiction, and this gives rise to variation in minimum wages both across jurisdictions and over time (Hamermesh 2002: 716, 717). This is in contrast to countries with a uniform national minimum wage such as the USA, where minimum wage changes occur infrequently, and identification tends to come from state 'topups', differences in coverage, or the slow erosion of the real value of the minimum wage as its 'real' value falls relative to the average wage of the state.

The minimum wage increases ranged from $\$ 0.10$ to $\$ 1.00$, with the modal increase of $\$ 0.25$ occurring seven times, and with the mean increase of $\$ 0.28$ being close to the modal value. The mean increase of $\$ 0.28$ is a 5 per cent increase over the average minimum wage of $\$ 5.59$ over our data period. There are 5,695 individuals in our sample based on the broadest definition of the control group, and 156 based on the 'tight' control group of a $\$ 0.25$ bound above the minimum wage in provinces that did not experience a minimum wage increase. In all cases, there are 61 observations in the treatment group affected by minimum wage increases, raising the risk that it will not be possible to detect impacts from such a small group that is affected. In spite of this, as outlined subsequently, fairly substantial and significant effects are generally found.

Table 2 presents descriptive statistics (average characteristics) for older workers in the treatment group of minimum wage jobs, as well as for three control groups: the tightest low-wage comparison group of those in a jurisdiction that did not have a minimum wage increase but whose wage fell within the range of the minimum wage in their jurisdiction and $\$ 0.25$ above their minimum wage; the 'broadest' comparison group consists of all persons with a wage above the minimum wage in their province but who did not have a minimum wage increase; and our in-between preferred comparison group whose wage fell within the range of the minimum wage in their jurisdiction and $\$ 1.00$ above their minimum wage, which encompasses the actual range of minimum wage increases that occurred in our data.

As indicated, 80 per cent of minimum wage workers (column 1) were employed after their minimum wage increase. As expected, slightly lower proportions ( 77 per cent) were employed in the very low-wage or tight comparison group (column 2), reflecting their employment instability, higher proportions (87 per cent) were employed in the higher-wage control group (column 4), reflecting their employment stability, and the exact same proportion ( 80 per cent) were employed in our preferred comparison group (column 3) - providing further justification for the preferred comparison group. 
TABLE 2

Summary Statistics (Means) for the Treatment Group (Minimum Wage Jobs) and Three Control Groups (MINW + 25, MINW + 100 and MINW + ALL)

\begin{tabular}{lcccc}
\hline Variables & $\begin{array}{c}\text { Treatment } \\
\text { group } \\
(1)\end{array}$ & $\begin{array}{c}\text { Control group } \\
(M I N W+25) \\
(2)\end{array}$ & $\begin{array}{c}\text { Control group } \\
(M I N W+100)\end{array}$ & $\begin{array}{c}\text { Control group } \\
(M I N W+A L L)\end{array}$ \\
\hline Employed & 0.80 & 0.77 & 0.80 & $(4)$ \\
Male & 0.21 & 0.23 & 0.23 & 0.87 \\
Married & 0.77 & 0.81 & 0.77 & 0.53 \\
Education [<high school] & 0.54 & 0.37 & 0.48 & 0.83 \\
High school diploma & 0.34 & 0.28 & 0.23 & 0.29 \\
Non-university certificate & 0.08 & 0.30 & 0.23 & 0.22 \\
University degree & 0.03 & 0.05 & 0.06 & 0.32 \\
Union job & 0.03 & 0.05 & 0.06 & 0.17 \\
Industry [service] & 0.51 & 0.53 & 0.48 & 0.46 \\
Primary & 0.07 & 0.02 & 0.04 & 0.48 \\
Manufacturing & 0.05 & 0.08 & 0.08 & 0.16 \\
Construction & 0.02 & 0.01 & 0.01 & 0.03 \\
Transportation & 0.03 & 0.00 & 0.01 & 0.08 \\
Trade & 0.30 & 0.35 & 0.36 & 0.13 \\
Finance/real estate & 0.00 & 0.01 & 0.02 & 0.05 \\
Industry unknown & 0.03 & 0.00 & 0.02 & 0.04 \\
Immigrant & 0.15 & 0.23 & 0.24 & 0.19 \\
Visible minority & 0.02 & 0.08 & 0.10 & 0.04 \\
Firm size [<20 employees] & 0.59 & 0.61 & 0.53 & 0.21 \\
20-99 employees & 0.21 & 0.16 & 0.15 & 0.15 \\
100-499 employees & 0.07 & 0.08 & 0.09 & 0.14 \\
500 or more employees & 0.12 & 0.13 & 0.21 & 0.48 \\
Firm size unknown & 0.02 & 0.02 & 0.02 & 0.01 \\
Unemployment rate & 11.5 & 8.92 & 9.14 & 9.02 \\
Year [1994] & 0.15 & 0.14 & 0.13 & 0.09 \\
Year 1995 & 0.05 & 0.12 & 0.12 & 0.13 \\
Year 1996 & 0.23 & 0.05 & 0.08 & 0.07 \\
Year 1997 & 0.13 & 0.12 & 0.12 & 0.14 \\
Year 1998 & 0.25 & 0.40 & 0.36 & 0.40 \\
Year 1999 & 0.20 & 0.17 & 0.19 & 0.18 \\
\hline Note: Excluded referen & & & & \\
\hline
\end{tabular}

Note: Excluded reference group in square brackets.

MINW, minimum wage.

As indicated in the first column, minimum wage jobs tend to be disproportionately female, involving less education, and in the service and trade industries and in small firms. This also tends to be the case for our preferred comparison group, and less so for the low-wage comparison group and especially the higher-wage comparison groups, again adding further credence for the preferred comparison group.

\section{Results}

\section{Full Regression, Minimum Wage and Controls}

Table 3 presents the full regression results for one of the 22 regressions (11 comparison groups with wages above the minimum wage in their jurisdiction, and 11 with wages both above and below the minimum wage). Results for full 
TABLE 3

Probit Estimates of Minimum Wages and Control Variables on the Employment Continuation Probability for Older Workers (50+), Based on Preferred Comparison Group of MINW + 100 Sample

\begin{tabular}{lcr}
\hline Variables & Marginal effects & t-statistic \\
\hline MINW + 100 & 0.140 & 2.38 \\
Male & 0.001 & 0.04 \\
Married & 0.036 & 0.56 \\
Education [<high school] & & \\
High school diploma & -0.064 & -1.17 \\
Non-university certificate & -0.170 & -2.09 \\
University degree & -0.115 & -0.97 \\
Union job & 0.147 & 1.59 \\
Industry [service] & & \\
Primary & -0.105 & -0.60 \\
Manufacturing & -0.044 & -0.45 \\
Trade & -0.037 & -0.77 \\
Industry unknown & -0.179 & -0.94 \\
Immigrant & -0.043 & -0.65 \\
Visible minority & 0.042 & 0.52 \\
Firm size [less than 20 employees] & & \\
20-99 employees & -0.148 & -1.99 \\
100-499 employees & 0.061 & 0.86 \\
500 or more employees & -0.019 & -0.30 \\
Firm size unknown & -0.055 & -0.29 \\
Unemployment rate & 0.002 & 0.03 \\
Year [1994] & 0.012 & \\
Year 1995 & -0.037 & 0.19 \\
Year 1996 & 0.016 & -0.56 \\
Year 1997 & 0.046 & 0.10 \\
Year 1998 & -0.085 & 0.53 \\
Year 1999 & -0.72 \\
\hline
\end{tabular}

Notes: $t$-statistics are based on robust standard errors clustered by province. Excluded reference group in square brackets.

MINW, minimum wage.

regressions for the other 21 equations are available from the authors on request. This illustrative regression is based on our preferred comparison group of persons whose wage was within $\$ 1.00$ above the minimum wage in their jurisdiction - the group whose wages were within the range of the actual minimum wage increases that occurred in our data.

Since the dependent variable is dichotomous (coded 1 if employed in the subsequent year, 0 if otherwise), probit estimation is utilized to confine predicted values to the unit interval, thereby giving a probability interpretation. These are converted to marginal effects so as to indicate the effect of minimum wages and the controls on the probability of being employed in a given year, conditional upon having been employed in the previous year. The probit results are similar to those based on OLS estimates of a linear probability function (available from the authors on request).

As indicated in the first row, minimum wages have a statistically significant and positive effect on the employment of older workers. The coefficient of 0.140 suggests that older workers whose wage was affected by a minimum 
wage increase were a statistically significant 14 percentage points more likely to be employed the next year compared with otherwise similar low-wage workers in provinces whose wages were not affected by a minimum wage increase. This is a substantial difference, perhaps reflecting a substitution from a relative large number of younger minimum wage workers into a small number of older minimum wage workers (as discussed subsequently).

The results for the control variables are unsurprising, except for the negative effect of higher education on the probability of remaining employed in the subsequent period, albeit the impacts are generally statistically insignificant. Since these are older workers, it is not clear that higher education would secure their employability. Union workers are more likely to remain employed, reflecting their employment security. Workers in the Atlantic provinces and Quebec are less likely to remain employed, reflecting the employment instability in those regions.

\section{Effects for Alternative Comparison Groups}

Table 4 summarizes the minimum wage effects for the 22 different regressions based on 11 comparison groups with wages above the minimum wage (labelled MINW+) in their jurisdiction, and 11 with wages both above and below the minimum wage (labelled MINW+ or - ).

Overall, the impacts are positive and generally statistically significant at conventional levels. That is, older workers whose wages would be affected by minimum wage increases were more likely to remain employed in the following year compared with older workers in provinces whose wages were not affected by minimum wage increases. This is not only theoretically unexpected, but also at odds with even much of the 'new minimum wage literature' that sometimes found positive effects, but when positive, they were generally statistically insignificant. Clearly, our results for older workers are at odds with the results for youths as found in the general literature.

Importantly, the positive effect for older workers is the opposite of the substantial negative effect on employment found for youths in the recent Canadian literature ${ }^{5}$ based on different datasets and methodologies. It is also the opposite of the negative effect for youths found in Campolieti et al. (2005a) based on the same time period, specification and dataset. Clearly, the positive employment effect is not a Canadian phenomenon; it is an older worker phenomenon. Possible reasons for this will be discussed in the conclusion.

The positive employment effect is robust across all dimensions of the different specifications employed: the range of tight to broad comparison groups, and whether the comparison groups are based on those whose wages are above the minimum wage in their jurisdictions or both above and below that minimum wage.

The magnitude of the positive effect does decline monotonically as broader comparison groups are used, and it does become statistically insignificant for broad comparison groups whose wages exceed the minimum wage in their jurisdiction by around $\$ 3.00$ or more. This is expected, since these are less 
TABLE 4

Probit Estimates of Marginal Effects of Minimum Wages on the Employment Continuation Probability for Workers Aged 50+: Various Control Groups ( $t$-Statistic in Parentheses)

\begin{tabular}{|c|c|c|}
\hline Control groups & Sample size & Marginal effect \\
\hline MINW + 25 & 156 & $\begin{array}{r}0.250 \\
(2.30)\end{array}$ \\
\hline MINW + or -25 & 182 & $\begin{array}{l}0.227 \\
(2.06)\end{array}$ \\
\hline $\mathrm{MINW}+50$ & 199 & $\begin{array}{l}0.208 \\
(2.03)\end{array}$ \\
\hline MINW + or - 50 & 246 & $\begin{array}{l}0.193 \\
(1.82)\end{array}$ \\
\hline MINW + 75 & 279 & $\begin{array}{c}0.151 \\
(2.01)\end{array}$ \\
\hline MINW + or - 75 & 348 & $\begin{array}{l}0.150 \\
(1.92)\end{array}$ \\
\hline MINW + 100 & 326 & $\begin{array}{r}0.140 \\
(2.38)\end{array}$ \\
\hline MINW + or - 100 & 389 & $\begin{array}{l}0.134 \\
(2.14)\end{array}$ \\
\hline MINW + 150 & 452 & $\begin{array}{r}0.135 \\
(2.10)\end{array}$ \\
\hline MINW + or - 150 & 533 & $\begin{array}{c}0.129 \\
(1.95)\end{array}$ \\
\hline MINW + 200 & 566 & $\begin{array}{c}0.118 \\
(1.79)\end{array}$ \\
\hline MINW + or -200 & 659 & $\begin{array}{r}0.115 \\
(1.73)\end{array}$ \\
\hline MINW + 250 & 650 & $\begin{array}{c}0.107 \\
(1.57)\end{array}$ \\
\hline MINW + or -250 & 759 & $\begin{array}{l}0.110 \\
(1.70)\end{array}$ \\
\hline MINW + 300 & 769 & $\begin{array}{l}0.098 \\
(1.36)\end{array}$ \\
\hline MINW + or -300 & 877 & $\begin{array}{c}0.100 \\
(1.46)\end{array}$ \\
\hline MINW + 350 & 912 & $\begin{array}{l}0.095 \\
(1.29)\end{array}$ \\
\hline $\mathrm{MINW}+$ or -350 & 1033 & $\begin{array}{l}0.097 \\
(1.37)\end{array}$ \\
\hline MINW + 400 & 1030 & $\begin{array}{c}0.088 \\
(1.30)\end{array}$ \\
\hline MINW + or -400 & 1145 & $\begin{array}{r}0.090 \\
(1.34)\end{array}$ \\
\hline MINW + ALL & 5578 & $\begin{array}{c}0.042 \\
(0.63)\end{array}$ \\
\hline MINW + or - ALL & 5695 & $\begin{array}{c}0.044 \\
(0.67)\end{array}$ \\
\hline
\end{tabular}

Notes: $t$-statistics are based on robust standard errors clustered by province.

MINW, minimum wage.

preferred comparison groups because they disproportionately include higher wage persons who are likely to have greater employment stability than those who are affected by minimum wages.

As discussed previously, the comparison group whose wage was between the minimum wage in their jurisdiction and $\$ 1.00$ above that wage is our 
preferred comparison group, since it is within the range of actual minimum wage increases that occurred in our data. The coefficient of 0.140 on the minimum wage variable suggests that older workers whose wage was affected by a minimum wage increase were a statistically significant 14 percentage points more likely to be employed the next year compared with otherwise similar low-wage workers whose wages were not affected by a minimum wage increase. The magnitude was very similar (ranging from 0.13 to 0.15 ) for other reasonable comparison groups broadened to include persons whose wage also was up to $\$ 1.00$ below the minimum in their jurisdiction (MINW + or -100 ) or persons whose wage was up to $\$ 1.50$ above or below the minimum in their jurisdiction (MINW + or $-\$ 1.50$ ), or if it was narrowed, to include only those whose wage was $\$ 0.75$ above or below the minimum in their jurisdiction (MINW + or - 75). The statistical significance and the magnitude of the minimum wage impacts appear robust across alternative reasonable control groups.

\section{Gap and Gap Variant Estimates}

As indicated previously, we also use a gap measure of the magnitude of the increase in the individual's wage necessary to bring it to the minimum wage so as to exploit the considerable variation in the actual magnitude of the wage adjustment necessary to bring individuals up to the new minimum wage. We also use a gap variant that also controls for within-group heterogeneity. These results are presented in Table 5, along with those of the at-risk methodology for comparison purposes. We restrict the analysis to comparison groups with wages above the minimum wage in their jurisdiction that did not increase their minimum wage, since those below the minimum may reflect measurement error or non-compliance that would remain in non-compliance.

The pattern of positive and generally statistically significant effects for reasonable control groups that prevailed in the at-risk methodology also prevailed in both the gap and gap variant methodology. The results for the gap methodology were also generally very close to those of the gap variant.

The marginal effects for the gap estimates indicate the effect of a one-unit (i.e. \$1.00) increase in wages from a minimum wage increase. Multiplying these marginal effects by the average minimum wage increase of $\$ 0.28$ that occurred in our data yields the expected impact of the average minimum wage change on the probability of being employed. As indicated, these effects are very similar for the gap and gap variant methods (columns 4 and 6 , respectively), and they are similar to the magnitudes for the at-risk methodology (column 2). Again the results appear robust, in this case across different gap methodologies and between them and the at-risk methodology.

\section{Conclusion and discussion}

As a conservative statement, it certainly seems safe to say that minimum wage increases have not led to adverse employment effects for older workers 
TABLE 5

Gap and Gap Variant Methods - Probit Estimates of Marginal Effects of Minimum Wages on the Employment Continuation Probability for Workers Aged 50+, Various Control Groups ( $t$-Statistic in Parentheses)

\begin{tabular}{|c|c|c|c|c|c|c|}
\hline \multirow[t]{2}{*}{$\begin{array}{l}\text { Control } \\
\text { groups }\end{array}$} & \multirow[t]{2}{*}{$\begin{array}{l}\text { Sample size } \\
\text { (1) }\end{array}$} & \multirow{2}{*}{$\begin{array}{c}\begin{array}{c}\text { At-risk } \\
\text { methodology }\end{array} \\
\begin{array}{c}\text { Marginal } \\
\text { effects } \\
(2)\end{array}\end{array}$} & \multicolumn{2}{|c|}{$\begin{array}{c}\text { Gap } \\
\text { methodology }\end{array}$} & \multicolumn{2}{|c|}{ Gap variant } \\
\hline & & & $\begin{array}{l}\text { Marginal } \\
\text { effects } \\
\text { (3) }\end{array}$ & $\begin{array}{l}\text { Impact on } \\
\text { employment } \\
\text { (4) }\end{array}$ & $\begin{array}{c}\text { Marginal } \\
\text { effects } \\
\text { (5) }\end{array}$ & $\begin{array}{l}\text { Impact on } \\
\text { employment } \\
\text { (6) }\end{array}$ \\
\hline MINW + 25 & 156 & $\begin{array}{c}0.250 \\
(2.30)\end{array}$ & $\begin{array}{l}0.846 \\
(2.15)\end{array}$ & 0.237 & $\begin{array}{r}0.921 \\
(2.39)\end{array}$ & 0.258 \\
\hline $\mathrm{MINW}+50$ & 199 & $\begin{array}{c}0.208 \\
(2.03)\end{array}$ & $\begin{array}{c}0.924 \\
(2.00)\end{array}$ & 0.259 & $\begin{array}{l}0.923 \\
(1.89)\end{array}$ & 0.258 \\
\hline $\mathrm{MINW}+75$ & 279 & $\begin{array}{l}0.151 \\
(2.01)\end{array}$ & $\begin{array}{l}0.758 \\
(2.47)\end{array}$ & 0.212 & $\begin{array}{c}0.747 \\
(2.10)\end{array}$ & 0.209 \\
\hline $\mathrm{MINW}+100$ & 326 & $\begin{array}{r}0.140 \\
(2.38)\end{array}$ & $\begin{array}{l}0.651 \\
(2.87)\end{array}$ & 0.182 & $\begin{array}{c}0.628 \\
(2.74)\end{array}$ & 0.176 \\
\hline MINW + 150 & 452 & $\begin{array}{l}0.135 \\
(2.10)\end{array}$ & $\begin{array}{l}0.562 \\
(2.22)\end{array}$ & 0.157 & $\begin{array}{r}0.527 \\
(2.20)\end{array}$ & 0.148 \\
\hline MINW + 200 & 566 & $\begin{array}{l}0.118 \\
(1.79)\end{array}$ & $\begin{array}{l}0.516 \\
(2.34)\end{array}$ & 0.144 & $\begin{array}{c}0.449 \\
(2.04)\end{array}$ & 0.126 \\
\hline MINW + 250 & 650 & $\begin{array}{l}0.107 \\
(1.57)\end{array}$ & $\begin{array}{l}0.445 \\
(2.23)\end{array}$ & 0.125 & $\begin{array}{l}0.396 \\
(2.10)\end{array}$ & 0.111 \\
\hline MINW + 300 & 769 & $\begin{array}{l}0.098 \\
(1.36)\end{array}$ & $\begin{array}{r}0.390 \\
(1.91)\end{array}$ & 0.109 & $\begin{array}{c}0.309 \\
(1.59)\end{array}$ & 0.087 \\
\hline MINW + 350 & 912 & $\begin{array}{l}0.095 \\
(1.29)\end{array}$ & $\begin{array}{l}0.382 \\
(1.87)\end{array}$ & 0.107 & $\begin{array}{l}0.306 \\
(1.66)\end{array}$ & 0.086 \\
\hline $\mathrm{MINW}+400$ & 1030 & $\begin{array}{c}0.088 \\
(1.30)\end{array}$ & $\begin{array}{c}0.348 \\
(1.93)\end{array}$ & 0.097 & $\begin{array}{c}0.268 \\
(1.72)\end{array}$ & 0.075 \\
\hline MINW + ALL & 5578 & $\begin{array}{r}0.042 \\
(0.63)\end{array}$ & $\begin{array}{c}0.203 \\
(1.32)\end{array}$ & 0.057 & $\begin{array}{r}0.147 \\
(1.01)\end{array}$ & 0.041 \\
\hline
\end{tabular}

Note: $t$-statistics are based on robust standard errors clustered by province. MINW, minimum wage.

as they have for youths in Canada. If anything, they are associated with positive employment effects.

What could account for this theoretically unexpected positive and generally statistically significant impact of minimum wages on older workers? As indicated, it is at odds with even some of the new minimum wage literature for youths that often found zero impacts and occasionally even found positive impacts, but, when positive, they were generally statistically insignificant. It is also at odds with recent Canadian studies that find fairly substantial negative impacts for youths. In essence, any explanation of the positive impact for older workers must be consistent with why the opposite effect is found for youths in Canada.

Employers may be more reluctant to lay off older workers than youths, but this explanation would be more consistent with a zero impact for older workers and a negative one for youths. The adverse employment effect is more likely to occur in the form of the counterfactual of slower employment growth rather than actual layoffs as well, and it is not obvious why this 
slower employment growth should not be as pronounced for older workers than for youths when both are subject to a minimum wage increase.

Shock effects on employers or employees may explain the absence of an adverse employment effect. Employers and managers, for example, may be shocked by the cost increase of minimum wages to adopt more efficient practices in other areas. Employees who receive a minimum wage increase may be more motivated and committed, yielding cost saving in the form of reduced turnover - an efficiency wage response where the higher wages induce higher productivity. Apart from the issue of why employers would not have voluntarily raised wages without the minimum wage if wage increases induce such a response, it is not obvious why the response should be greater for older workers compared with younger workers. And it is not obvious why it should increase the employment of older workers affected by a minimum wage increase compared with those not affected, as opposed to possibly offsetting any adverse employment effect.

Employers behaving monopsonistically can also give rise to positive employment effects from a minimum wage at least over a range of wage increases (Card and Krueger 1995a; Manning 2003; Metcalf 2008). In such circumstances, employers are reluctant to raise wages to attract or increase the flow of new recruits, since the higher wages would have to be paid to their incumbent workers to maintain equity in their internal wage structure. The cost of hiring additional workers increases not only by the higher wage required to recruit, but also by the upward adjustment to the wages of incumbents to maintain internal equity. With a minimum wage, however, such employers are no longer inhibited in their hiring by this constraint; they have to pay the minimum wage to their incumbent low-wage workers, as well as new low-wage recruits. In such circumstances, they may actually increase their hiring flows, since the cost of doing so does not increase by more than the minimum wage, while prior to the minimum wage, it increased by the higher wage required to recruit, as well as the upward adjustment to the wages of incumbents to maintain internal equity. A monopsony explanation would seem reasonable for a positive employment effect, in part because it seems reasonable that employers would be concerned about the implications of raising wages to recruit because of what this would do to their internal wage structure. It is not obvious, however, why this should apply only to older workers and not to youths. Perhaps raising wages to recruit older workers as opposed to younger workers is more likely to invite invidious comparisons within the low-wage older internal workforce of firms. It is also possible that the conditions that give rise to monopsony (e.g. restricted mobility, preferences to work for the local employer) are more applicable to older workers than younger workers, especially for older workers who are working mainly to keep active rather than for the pay.

It is even possible that positive employment effects for older workers have been estimated, but they have not been published because of a possible bias against publishing results that are statistically insignificant or theoretically 
unexpected. Evidence of such a bias in the minimum wage literature is provided in Card and Krueger (1995b).

The argument that we believe has the most credibility is that increases in the employment of older workers could occur if employers substituted away from the least productive workers and towards the more productive workers when both are subject to a minimum wage increase. In this case, the least productive are arguably teenagers (who have few skills and little experience), and those more productive are arguably older workers (who have considerable experience and may be using these low-wage jobs as a way to supplement retirement income or to keep occupied). Older workers may be more qualified for the minimum wage jobs than are younger workers, especially because many older workers may be working in low-paid jobs to simply bridge their transition to retirement and perhaps back from retirement, rather than working for the pay.

\section{Acknowledgements}

Financial assistance from the SSHRC is gratefully acknowledged, as are comments received at the Conference on 100 Years of Minimum Wage Regulation held at the LSE on 13-14 December 2007.

\section{Notes}

1. Reviews of the extensive literature are contained in Brown (1999) and Card and Krueger (1995a), Gunderson (2005), Kennan (1995), Neumark and Wascher (2007), and OECD (1998), with a review of British evidence on the impact of the recent national minimum wage policy in Metcalf (2004).

2. Variants of the 'at-risk' methodology have been used in Abowd et al. (2000), Ashenfelter and Card (1981), Campolieti et al. (2005a,b), Currie and Fallick (1996), Linneman (1982), Yuen (2003), and Zavodny (2000).

3. An issue with all of the minimum wage literature is that of controlling for other factors that can influence employment, including shifts in labour supply that, as indicated, are occurring for older workers. Unfortunately, direct evidence does not exist on the sources of the increased supply of older minimum wage workers. Indirect evidence, however, suggests that little of it comes from older workers who have a stable employment history in minimum wage jobs (Carrington and Fallick 2001, Long 1999 and earlier references cited therein). Most of it comes from older workers who have returned to work after retiring from higher-paying jobs. Gomez and Gunderson (2005: 6), for example, indicate that 23 per cent of retirees in Canada return to work, generally in lower-paying jobs compared with the job from which they retired. While the supply influx of older workers can go into minimum wage jobs, it is not obvious that it would have a differential impact on the treatment groups that experience a minimum wage increase and the range of reasonable 
control groups (discussed subsequently) that are in jobs that pay around the minimum wage but that do not experience a minimum wage increase, especially after including control variables for other factors that affect employment (which was also discussed subsequently).

4. Statistics Canada restricts access to the master files for confidentiality purposes; hence, the actual regression runs were done internally at Statistics Canada.

5. The recent Canadian studies are Baker (2005), Baker et al. (1999), Campolieti et al. (2005a,b), Campolieti et al. (2006) and Yuen (2003).

\section{References}

Abowd, J., Kramarz, F., Lemieux, T. and Margolis, D. (2000). 'Minimum wages and youth employment in France and in the US'. In D. Blanchflower and R. Freeman (eds.), Youth Employment and Joblessness in Advance Countries. Chicago: University of Chicago Press, pp. 427-72.

Ashenfelter, O. and Card, D. (1981). 'Using Longitudinal Data to Estimate the Employment Effects of the Minimum Wage'. Centre for Labour Economics, London School of Economics Discussion Paper 98.

Baker, M. (2005) 'Minimum Wages and Human Capital Investments of Young Workers: Work Related Training and School Enrolment'. HRSDC/IC/SSHRC Skills Research Initiative Working Paper 2005 B-04, 2005, Ottawa.

- Benjamin, D. and Stanger, S. (1999). 'The highs and lows of the minimum wage effect: a time-series cross-section study of the Canadian law'. Journal of Labor Economics, 17: 318-50.

Brown, C. (1999). 'Minimum wages, employment, and the distribution of income'. In O. Ashenfelter and D. Card (eds.), Handbook of Labor Economics, 1st edn, vol. 3B. Amsterdam: Elsevier, pp. 2101-64.

Campolieti, M., Fang, T. and Gunderson, M. (2005a). 'Minimum wage impacts on employment transitions of youths: 1993-99'. Canadian Journal of Economics, 38: 81-104.

- - - and (2005b). 'How minimum wages affect schooling-employment outcomes in Canada'. Journal of Labor Research, 26: 533-45.

- Gunderson, M. and Riddell, C. (2006). 'Minimum wage impacts from a prespecified research design: Canada 1981-1997'. Industrial Relations, 45: 195216.

Card, D. and Krueger, A. (1995a). Myth and Management: The New Economics of the Minimum Wage. Princeton, NJ: Princeton University Press.

_ and _ (1995b). 'Time series minimum wage studies: a meta-analysis'. American Economic Review Papers and Proceedings, 85 (2): 238-43.

Carone, G. (2005). Long-Term Labour Force Projections for the 25 EU States. Brussels: European Commission.

Carrington, W. J. and Fallick, B. C. (2001). 'Do some workers have minimum wage careers?' Monthly Labor Review, 124: 17-27.

Currie, J. and Fallick, B. (1996). 'The minimum wage and the employment of youth'. Journal of Human Resources, 31: 404-28.

Gomez, R. and Gunderson, M. (2005). The Aging Workforce and its Transitions to Retirement. Ottawa: Human Resources Development Canada.

Gunderson, M. (2005). Minimum Wages in Canada: Theory, Evidence and Policy. Ottawa: Federal Labour Standard Review Commission. 
Hamermesh, D. S. (2002). 'International labour economics'. Journal of Labor Economics, 20: 709-32.

Kennan, J. (1995). 'The elusive effect of minimum wages'. Journal of Economic Literature, 33: 1950-65.

Linneman, P. (1982). 'The economic impacts of minimum wage laws: a new look at an old question'. Journal of Political Economy, 90: 443-69.

Long, J. E. (1999). 'Updated estimates of the wage mobility of minimum wage workers'. Journal of Labor Research, 20: 493-504.

Manning, A. (2003). Monopsony in Motion. Princeton, NJ: Princeton University Press.

Martel, L., Caron-Malenfant, C., Vézina, S. and Bélanger, A. (2007). 'Labour force projections for Canada, 2006-2031'. Canadian Economic Observer, 20.

Metcalf, D. (2004). 'The impact of the national minimum wage on the pay distribution, employment and training'. Economic Journal, 114: C84-6.

- (2008). 'Why has the British national minimum wage had little or no impact on employment?' Journal of Industrial Relations, 50: 489-512.

Neumark, D. and Wascher, W. (2007). 'Minimum wages and employment'. Foundations and Trends in Microeconomics, 3 (1-2): 1-182.

OECD (1998). 'Making the most of the minimum wage: statutory minimum wages, employment and poverty'. In Employment Outlook. Paris: Organisation for Economic Co-Operation and Development, pp. 31-79.

Tossi, M. (2005). 'Labor force projections to 2014: retiring boomers.' Monthly Labor Review, 129 (11): 25-44.

United Nations (2002). United Nations World Population Projections: The 2002 Revsions, Volume II: Sex and Age. New York: United Nations.

Yuen, T. (2003). 'The effect of minimum wages on youth employment in Canada: a panel study'. Journal of Human Resources, 38: 647-72.

Zavodny, M. (2000). 'The effect of the minimum wage on employment and hours'. Labour Economics, 7: 729-50. 